\section{Chris Rouse}

is a director of Insignia Hotel Partners and has over 20 years' experience in the development of hotels, having been development director for Copthorne Hotels, based in both Spain and the UK, Mandarin Oriental Hotel Group, based in Hong Kong, and BAA Hotels and Forte plc, both in the UK.

\section{Serge Sonti}

is director of hospitality analysis with Insignia Hotel Partners, providing analytical support to European

transactions and working closely with senior associates on complex assignments. During his previous experience in the hospitality consulting sector in Washington DC and Atlanta, he conducted real estate appraisals, impact studies, feasibility analyses and market portfolio evaluations for a cross-section of land uses. He has held hotel operations positions in the USA and Switzerland.

\section{Keywords:}

Europe, transactions, institutions, markets, development, growth
Christopher Rouse

Director,

Insignia Hotel Partners,

107 Cheapside,

London $\mathrm{EC}_{2} \mathrm{~V} 6 \mathrm{HX}$,

UK

Tel: +44 (o) 2074910404

Fax: +44 (0) 2072367668

E-mail:

chris.rouse@insigniahotelpartners. com

\section{Review and analysis of transaction and development activity in the European hotel market in $\mathbf{2 0 0 0}$}

\section{Chris Rouse and Serge Sonti}

Received (in revised form): 14 May 2001

\begin{abstract}
The millennium year was notably the first year in which the value of hotel deals in the Eurozone dominated Europe's hotel transaction market. This paper examines where and why the deals were done and how the increasing interest of financial institutions is influencing the distribution of deals within the European market.
\end{abstract}

There is little doubt that the focus of transaction activity in 2000 was within the countries that form the European Economic and Monetary Union (EMU) and which will adopt the euro in 2002. The Eurozone ${ }^{1}$ saw the total value of hotel deals within its 12 member countries rise by 42 per cent from the level achieved in 1999 - which was in itself a 50 per cent increase over the previous year. Deals in the Eurozone topped $€ 3$ bn in 2000, an unprecedented level when compared to the $€ 1.4 \mathrm{bn}$ completed in 1998. The Eurozone (as well as the non-UK non-Eurozone) has achieved steady growth over the last few years.

In contrast, during 2000 transaction activity in the UK was subdued and reached only $€ 1.98 \mathrm{bn}$. Transaction activity in the UK peaked during 1999, when approximately $€ 4$.6bn of deals were completed after the five-year low ( $€ 1.9 \mathrm{bn})$ experienced in 1998.

1998

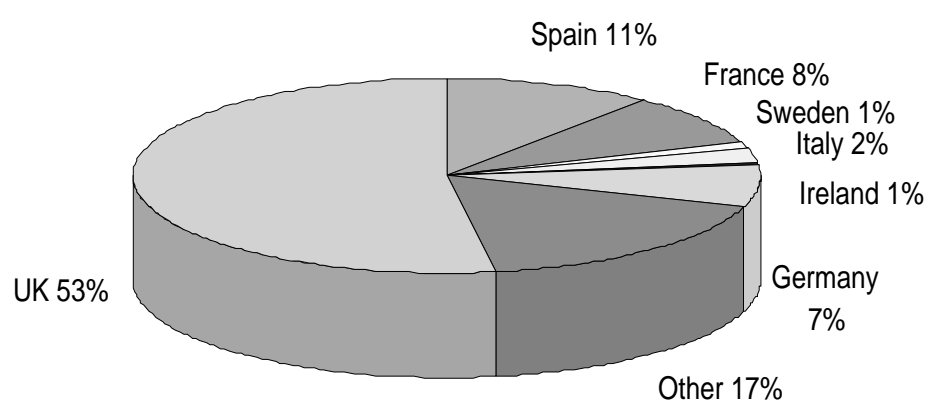

Figure I: European transactions 1998-2000 

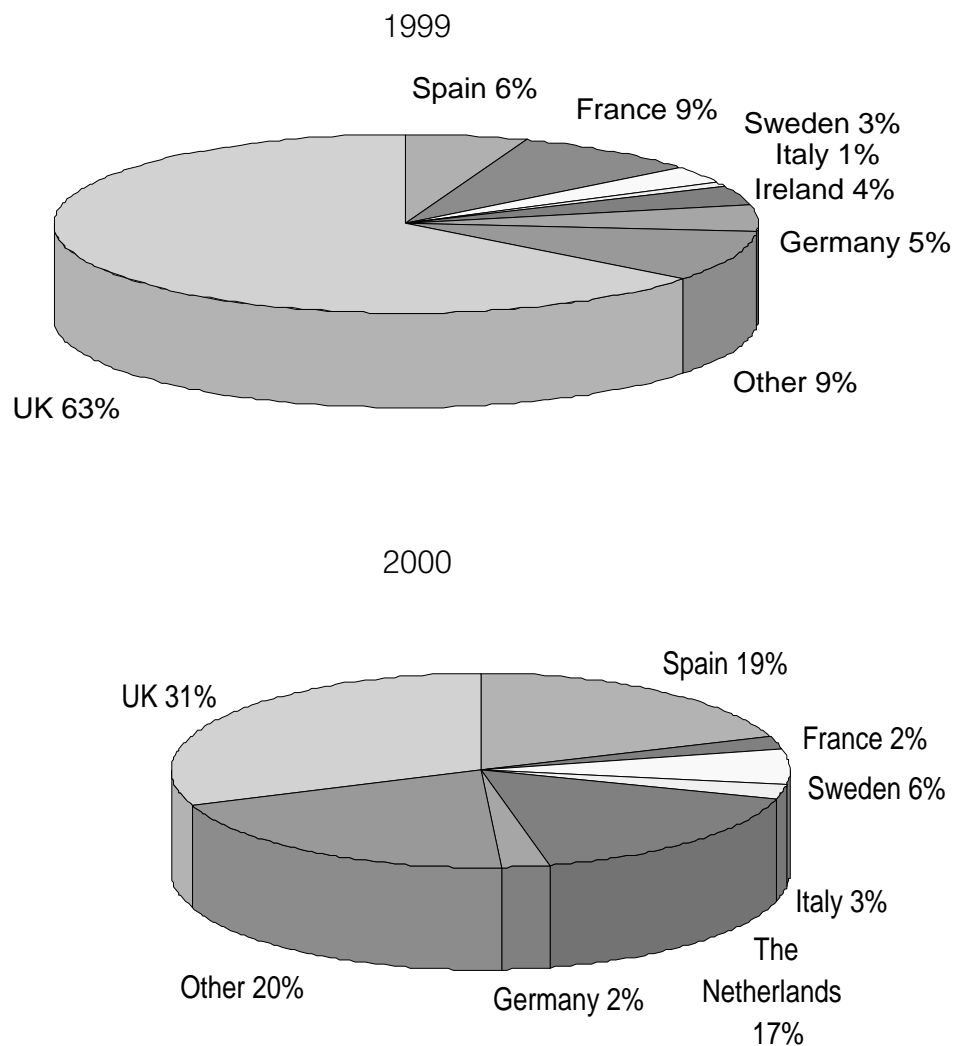

Total transactions in Eurozone exceeds UK and non-Eurozone

In the non-UK non-Eurozone countries, growth in transaction activity has been exponential - making up about 10 per cent of the non-Eurozone deals in 1998 at $€ 200 \mathrm{~m}$. This rose to $€ 500 \mathrm{~m}$ in 1999 and to around $€ 1 \mathrm{bn}$ in 2000, representing around 30 per cent of the non-Eurozone total.

In 2000 , for the first time, the total volume of transactions recorded in the Eurozone exceeded the approximate combined value of transactions in the UK and non-Eurozone countries. The total transaction value recorded in the whole of Europe was $€ 6.4 \mathrm{bn}$ and this is particularly impressive when compared to the $€ 4.5 \mathrm{bn}$ in hotel deals recorded in the USA over the same period.

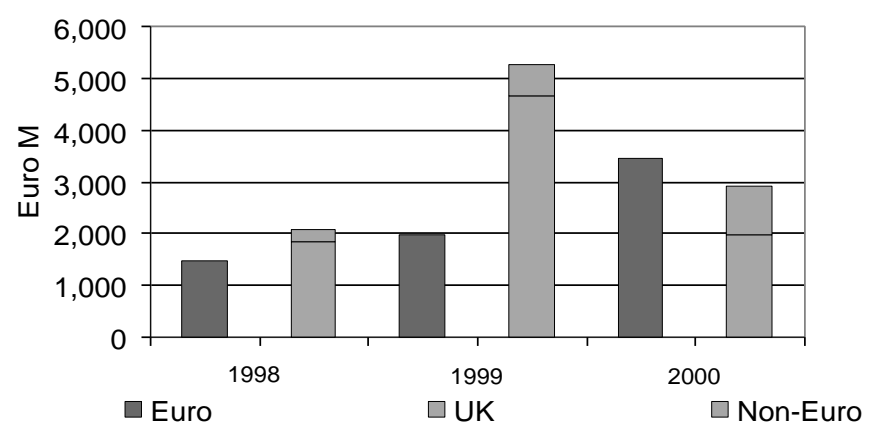

Figure 2: Eurozone versus non-Eurozone 
Table I: UK transactions

\begin{tabular}{|c|c|c|c|}
\hline & $\begin{array}{l}1998 \\
\epsilon_{000}\end{array}$ & $\begin{array}{l}1999 \\
\epsilon_{000}\end{array}$ & $\begin{array}{l}2000 \\
\epsilon_{000}\end{array}$ \\
\hline Single asset or portfolio & 752,751 & $1,207,178$ & $1,434,968$ \\
\hline Corporate deals & $1,104,515$ & $3,379,722$ & 540,077 \\
\hline Total transaction value & $1,857,267$ & $4,586,901$ & $1,975,045$ \\
\hline
\end{tabular}

Unlike the USA, Europe did not experience any systemic oversupply during the early 1990s. Development in Europe, at 2 per cent supply growth, lagged behind the USA which averaged a 4 per cent annual compound growth from 1996 to 1999. Development in the most desirable cities in Europe has traditionally been hindered by substantial barriers to entry, shortage of quality sites, cumbersome planning requirements and expensive conversion options. With many European countries further encumbered with serious tax liabilities on the sale of assets, many of the deals in continental Europe during 2000 were corporate transactions in nature.

\section{METHODOLOGY}

The Eurozone mainly comprises Western European and Mediterranean countries. Statistics for the UK, which elected not to join the EMU, are presented independently, also in part due to the UK's historic position as a large and self-contained hotel market with easily identifiable trends. This market is represented by deals done in England, Wales, Scotland and Northern Ireland. The nonUK non-Eurozone region comprises Scandinavia and most countries in Eastern Europe, including Turkey.

For the purposes of recording transaction values, deals have been recorded as being located in the country where the asset or majority of assets within a portfolio are located. Transaction values of large corporate deals have been collated by the country of origin of the acquired company. To derive comparative per-room data, an enterprise value was calculated from the transaction value.

For the purposes of this study, portfolio deals are those transactions that involved the transfer of a group of assets between two parties, while corporate deals are defined as those large portfolio transactions that involved the transfer of control in the ownership entity. Several single-asset and portfolio transactions may still involve the exchange of interest in the ownership entity.

\section{UK transactions}

\section{OVERVIEW OF TRANSACTIONS}

The 58 per cent fall in the level of total transactions completed in the UK during 2000 is attributable to a considerable decrease in corporate activity, coupled with a paucity of properties available through the year. The UK's share of transaction activity reached a staggering 63 per cent of the total transactions in Europe in 1999, only to fall back to about 30 per cent of the total value of deals done in 2000 throughout Europe. Of the $£ 540 \mathrm{~m}$ in transactions 


\section{Entry of third party investors}

concluded in the UK in 2000 , approximately $£ 300$ m worth were completed in December.

Although overall transaction activity in the UK was subdued, the market saw an increase in what is likely to be the dominant trend of future years, namely the entry of real estate investors and property funds into the hotel market, which effectively separates the ownership of the bricks from the operation of the hotel. These developments signal a move away from traditional European hotel investment practice and the acceptance of an effective model long recognised in the USA. During 2000, for example, London and Regional Properties were involved in the purchase of eight provincial Holiday Inn Expresses, which were subsequently rebranded as Ibis and are to be operated by the French company Accor. This transaction achieved a yield in excess of 7 per cent, but is expected to provide medium-term yields of 8.4 per cent with participation in the projected profits. Standard Life bought the Holiday Inn at Heathrow on an 8 per cent ingoing yield - a hotel with a trading history of only a few months, but located in a thriving airport hotel market. The trend was set by the groundbreaking Airport Investment Partnership investment fund sponsored by BAA Lynton, where investors bought into 90 per cent of the fund that owns eight prime airport hotel properties at a yield of 7.3 per cent. Other entities expected to invest in this sector during 2001 include the Royal Bank of Scotland's newly established hotel fund, Nomura and Friends Ivory \& Sime. These trends resulted in a preponderance of provincial transactions, as illustrated in Figure 3.

Among the single-asset transactions in London, the Cavendish Hotel in St James's and the St Ermin's Hotel both sold at yields approaching 9 per cent, high for city-centre properties, but reflective of the capital expenditure requirements of the properties. ${ }^{2}$

Traditional barriers to entry, including onerous tax liabilities on the transfer of assets, continue to result in the majority of continental European transactions largely comprising corporate deals. During 2000 several strategic mergers saw a number of

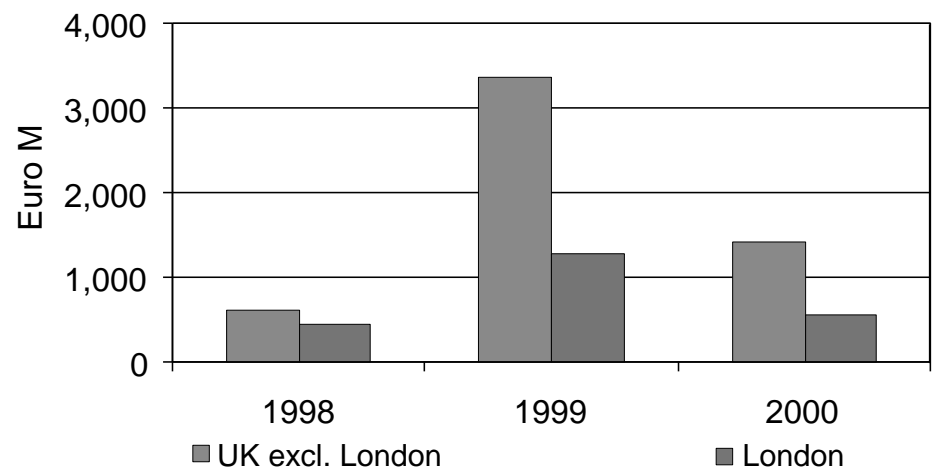

Figure 3: London versus regional UK 
Table 2: Continental Europe (Eurozone) transactions

\begin{tabular}{|c|c|c|c|}
\hline & $\begin{array}{l}1998 \\
\epsilon_{000}\end{array}$ & $\begin{array}{l}1999 \\
€ 000\end{array}$ & $\begin{array}{l}2000 \\
\epsilon_{000}\end{array}$ \\
\hline Single asset or portfolio & $1,349,951$ & $1,124,430$ & 870,396 \\
\hline Corporate deals & 117,051 & 849,860 & $2,597,806$ \\
\hline Total transaction value & $1,467,002$ & $1,974,320$ & $3,468,203$ \\
\hline
\end{tabular}

Eurozone transactions dominant domestic and international brands searching for further pan-European distribution.

Within the Eurozone, Spanish transactions represented 35 per cent of the overall activity in $2000 .^{3}$ Both NH Hoteles and Sol Melia were active domestically and in their pan-European endeavours. Sol Melia acquired all the outstanding shares in Tryp SA for $€ 360 \mathrm{~m}$ and NH Hoteles acquired 64 hotels comprising the Krasnopolsky chain, providing them with a strategic presence in the Benelux countries. Although no major corporate deals followed the Vivendi acquisition in France from the previous year, the largest single-asset transaction in France was the Hyatt Regency at Charles de Gaulle which sold to Hospitality Europe for approximately $€ 50 \mathrm{~m}$. The hotel was priced on a yield of 8 per cent but eventually yielded over 12.5 per cent in its first year, and is presently valued at 40 per cent over its acquisition cost. There were three major singleasset transactions in Germany during 2000, including the Renaissance Düsseldorf at approximately $€ 46 \mathrm{~m}$, the Marriott Hamburg at approximately $€ 45 \mathrm{~m}$ and the sale of two Kempinski hotels in Hamburg and Frankfurt to a group of private investors at approximately $€ 62 \mathrm{~m}$. The Kempinski hotels sold at yields reported at around 6 per cent, and were among only a small handful of deluxe hotels that sold during 2000 within the Eurozone.

The Vienna Crowne Plaza, which was sold to Immofinanz Immobilien Anlage, and the previously mentioned Marriott Hamburg transaction were both completed at a yield of 8 per cent, representing benchmarks in refinancing levels.

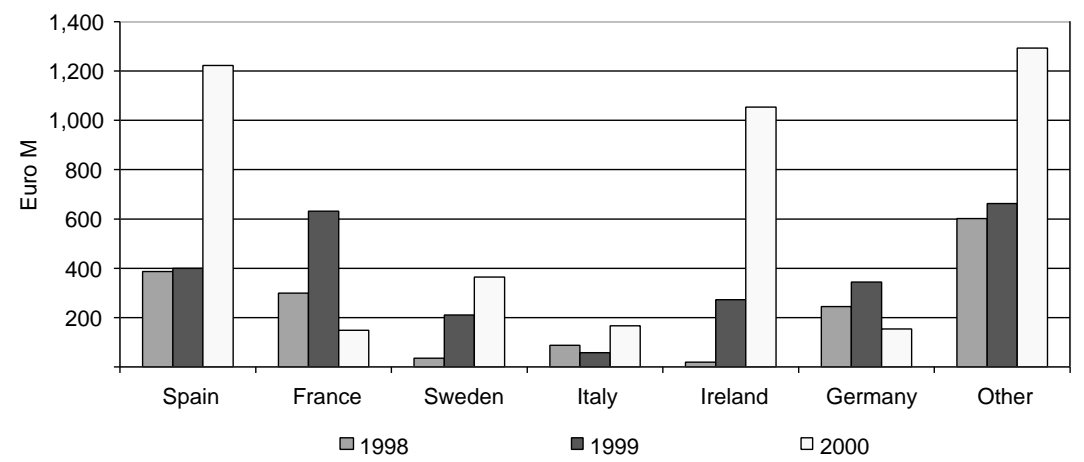

Figure 4: European transactions $1998-2000$ by country 
Scandinavian, Central and Eastern European transactions

Enhanced activity in Nordic regions
Of the cities experiencing enhanced development activity, Berlin was dominant in line with its new role as Germany's capital and Dublin has seen phenomenal activity in line with Ireland's strong economic growth. In anticipation of the summer Olympic Games in 2004 in Athens, there are 55 hotels in various stages of planning and construction of which 20 are promoted by the government. It is anticipated that Italy, the Netherlands and Spain will experience increased activity. Majorca, which has the most draconian restrictions on new hotels in Europe, saw the Eurozone's first sale reported at over $€ 1 \mathrm{~m}$ per room (Hotel Formentor in Puerto Pollensa).

\begin{tabular}{|c|c|c|c|}
\hline & $\begin{array}{l}1998 \\
\epsilon_{000}\end{array}$ & $\begin{array}{l}1999 \\
\epsilon_{000}\end{array}$ & $\begin{array}{l}2000 \\
\epsilon_{000}\end{array}$ \\
\hline Single asset or portfolio & 200,634 & 276,799 & 674,345 \\
\hline Corporate deals & 7,207 & 327,787 & 259,546 \\
\hline Total transaction value & 207,842 & 604,587 & 933,892 \\
\hline
\end{tabular}

The Scandinavian and Central and Eastern European region has experienced a boom in transaction activity over the last two years, and approached $€ 1 \mathrm{bn}$ in 2000 for the first time.

In the Czech Republic, the Renaissance Prague Hotel was bought by Hospitality Europe for the sum of $€ 71 \mathrm{~m}$, which represented a going-in yield of 12.5 per cent. Danubius, the largest Hungarian operator, purchased the majority stake in a chain of spa hotels in the Czech Republic mid-year. Linstow International acquired a 44.12 per cent stake in the Reval Hotel Group in Estonia. The New York Palace hotel in Budapest, Hungary, was sold to Boscolo, an Italian luxury hotel company and Accor, with German financial partners, bought 35.4 per cent of the state-owned Orbis chain in Poland.

Approximately $€ 600 \mathrm{~m}$ in transactions were completed in Scandinavia, during 2000, of which Scandic's activity dominated proceedings. The Swedish company, which has hotels in Sweden, UK and Germany, divested itself of the Hotellus group to Pandox and was the buyer of the Provobis chain of hotels and restaurants, which increased their Swedish portfolio to 74 hotels. In Norway, the bulk of transaction activity comprised the sale of two SAS Radisson hotels in Oslo. Choice Hotels Scandinavia purchased a well-distributed portfolio of 723 rooms in Denmark for approximately $€ 20 \mathrm{~m}$. Three of the seven hotels purchased were owned and four leased.

Scandinavia was a hotbed of development activity in 2000. In the midst of large-scale renovating and refurbishments in Copenhagen, two new five-star hotels - the Hilton Copenhagen (375 rooms) and the Copenhagen Marriott (395 rooms) — will open during 2001. 
Review and analysis of transaction and development activity in the European hotel market in 2000

Table 4: European transactions in 2000

\begin{tabular}{lllllr}
\hline Asset & City & Country & Rooms & Price (E) & Price/room (E) \\
\hline Single assets & & & & & \\
Caledonian Hotel & Edinburgh & UK & 249 & $72,000,000$ & 290,000 \\
Marriott Hamburg & Hamburg & Germany & 277 & $45,800,000$ & 165,000 \\
Cavendish St James's & London & UK & 251 & $97,000,000$ & 386,000 \\
Renaissance Prague & Prague & Czech Republic & 314 & $63,000,000$ & 201,000 \\
Hyatt Regency Charles & Paris & France & 388 & $50,000,000$ & 129,000 \\
de Gaulles & & & & \\
Hotel de la Tremoille & Paris & France & 107 & $22,400,000$ & 209,000 \\
Radisson SAS Oslo Plaza & Oslo & Norway & 491 & $56,200,000$ & 114,000 \\
Howard Hotel & London & UK & 143 & $65,400,000$ & 457,000 \\
St Ermin's & London & UK & 290 & $95,400,000$ & 329,000 \\
Portfolios & & & & \\
BAA Portfolios (8 hotels) & & UK & 2,945 & $311,600,000$ & 106,000 \\
Krasnapolsky (64 hotels) & & Netherlands & 10,000 & $830,000,000$ & 83,000 \\
Hotellus (16 hotels) & & Sweden & 3,589 & $263,000,000$ & 73,000 \\
Tryp Hoteles (60 hotels) & & Spain & 9,700 & $360,600,000$ & 37,000 \\
\hline
\end{tabular}

Source: Insignia Hotel Partners

Furthermore, a large city-centre commercial building in Copenhagen is to be turned into a 207-room hotel by Scandic. Eiendomspar and Rica Hotels have also announced the construction of a 300-room hotel between the city and Copenhagen airport, which will be linked to the Bella Centre's new convention facility. Two other hotels in advanced stages of planning in Copenhagen are the 150-room First Hotel Norregade and a 400room Rainbow Hotel.

In Stockholm, NCC AB are to develop a 300-room hotel, which is anticipated to be completed by the third quarter of 2002 .

Downtown, the 542-room Nordic Hotel is scheduled to open in the summer at Vasaplan. Over 700 new guest rooms are being built in Gothenburg in anticipation of the EU summit to be held in mid2001.

In Oslo a new 434-room hotel is being built on the waterfront by the train station, and was scheduled to open in May 2001.

Table 4 gives an overview of a select number of European transactions completed in 2000 .

\section{Strong growth in RevPAR during 2000}

\section{MAJOR TRENDS}

According to Andersen, ${ }^{4}$ there was a strong growth in RevPAR during 2000 throughout Europe, with over 19 principal cities experiencing double-digit growth rates. This constituted the third consecutive year of positive growth matched by increasing transaction activity. Over half the 29 cities surveyed by Andersen had occupancy levels between 70 and 80 per cent. Likewise, properties in approximately half the cities surveyed, which were restricted to quality hotels only, achieved annual average daily room rates (ADR) of between $€ 100$ and $€ 150$. Barcelona led RevPAR growth in the Eurozone with an increase of 26 per cent, followed closely by Amsterdam and Zurich. Brussels, Dublin, 
UK near peak of hotel performance
Madrid, Berlin, Munich and Paris recorded RevPAR growth rates in the region of 15 per cent over the previous year.

RevPAR growth in the non-UK non-Eurozone has been, for the most part, moderate when compared with continental Europe Stockholm leads the Nordic countries at 13 per cent. Although Andersen reports the highest recorded RevPAR growth in Eastern Europe in Istanbul at 48 per cent, this is an exaggerated figure due to the devastation to the tourism industry during 1999 caused by the combined effect of earthquakes and the crumbling Asian and Russian economies, the Kosovo war and repeated terrorist threats. In fact, 1999 was the worst year for the Istanbul hotel and tourism market ever recorded. Growth in Prague at 39 per cent ${ }^{5}$ far outstripped the rest of Central Europe, with Warsaw at 7 per cent and Budapest at 3 per cent.

Many European cities are in different stages of the hotel cycle. Andersen categorises the state of the market into four segments: those with a positive outlook, stable markets, those that have supply risk and recovery markets. The top 20 markets are illustrated in Figure 5.

Morgan Stanley Dean Witter ${ }^{6}$ do not agree completely with this outlook, stating that while the UK is near its peak, Spain and Italy are beginning to wane and France, the Netherlands, Sweden and Germany should be commencing a period of growth. However, the general consensus is a positive outlook for Europe, although the slowing down of the US economy may have an adverse effect on overall growth rates. Institutional investment will continue to grow, and the separation of the ownership entity from management is expected to drive transaction activity in 2001.

The strongest hotel markets in 2001 are projected to be the UK, with the advent of institutional investors and the impending Granada Compass disposal of the Forte assets; Scandinavia's

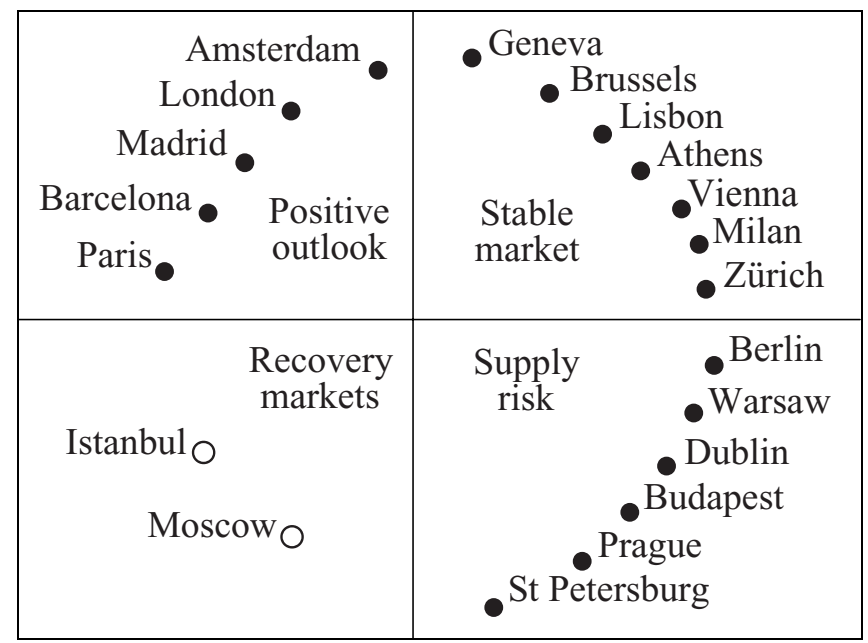

Source: Arthur Andersen

Figure 5: Top 20 European markets 
attractive and growth-laden hotel companies; ${ }^{7}$ and single assets in the Mediterranean countries.

\section{References}

1. The Eurozone comprises Austria, Belgium, Finland, France, Germany, Greece, Ireland, Italy, Luxembourg, the Netherlands, Portugal and Spain.

2. The sale of the Lanesborough at $£ 125 \mathrm{~m}$ in 2001 drove prices in London over $£ 1 \mathrm{~m}$ per room for the first time.

3. This includes the NH Hoteles Krasnopolsky transaction, which is shown as a Dutch transaction in Figure 1.

4. Andersen Hotel Industry Benchmark Survey 2001.

5. Parts of the RevPAR growth can be explained by a reduction in VAT rates on rooms from 22 per cent to 5 per cent in April 2000.

6. Britz, B., Rollo, J., Saiz, J-M., Ronceau, P. and Sala Vira, S. (2000) 'European Hotels: Industry Report', Morgan Stanley Dean Witter, September.

7. Hilton Group acquired Scandic in 2001 at a premium of 30.9 per cent at SEK144 per share, for a total transaction value of $€ 984.6 \mathrm{~m}$. Additionally, there is speculation over the future of the Radisson SAS group of hotels. 